\title{
Case Series and Review of Hematological and Non-Hematological Malignancies in Aging Patients with Sickle Cell Disease in the Hydroxyurea Era.
}

\author{
Sanaa Rizk \\ Thomas Jefferson University \\ David J. Axelrod \\ Thomas Jefferson University \\ Rasaq Olaosebikan \\ Thomas Jefferson University \\ Samir K. Ballas

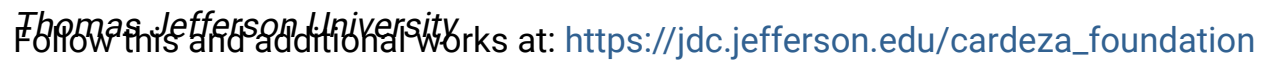 \\ Part of the Hematology Commons \\ Let us know how access to this document benefits you
}

\section{Recommended Citation}

Rizk, Sanaa; Axelrod, David J.; Olaosebikan, Rasaq; and Ballas, Samir K., "Case Series and Review of Hematological and Non-Hematological Malignancies in Aging Patients with Sickle Cell Disease in the Hydroxyurea Era." (2020). Cardeza Foundation for Hematologic Research. Paper 68.

https://jdc.jefferson.edu/cardeza_foundation/68

This Article is brought to you for free and open access by the Jefferson Digital Commons. The Jefferson Digital Commons is a service of Thomas Jefferson University's Center for Teaching and Learning (CTL). The Commons is a showcase for Jefferson books and journals, peer-reviewed scholarly publications, unique historical collections from the University archives, and teaching tools. The Jefferson Digital Commons allows researchers and interested readers anywhere in the world to learn about and keep up to date with Jefferson scholarship. This article has been accepted for inclusion in Cardeza Foundation for Hematologic Research by an authorized administrator of the Jefferson Digital Commons. For more information, please contact: JeffersonDigitalCommons@jefferson.edu. 


\section{Hematologic and non-hematologic malignancies in aging patients with sickle cell disease in the Hydroxyurea era.}

Sanaa Rizk ${ }^{1}$, David Axelrod ${ }^{2}$, Rasaq Olaosebikan ${ }^{3}$, Samir K. Ballas ${ }^{1}$.

${ }^{1}$ Cardeza Foundation for Hematologic Research, Department of Medicine, Sidney Kimmel

Medical College, Thomas Jefferson University, PA.

${ }^{2}$ Internal medicine department, Thomas Jefferson University, PA.

${ }^{3}$ Department of Pharmacology \& Experimental Therapeutics, Thomas Jefferson University, PA (supported by NIH training grant T32GM008562).

Keywords: malignancies, aging sickle cell patients, hydroxyurea.

\section{Introduction:}

Sickle cell disease is the most common genetic disease globally, with about 100,000 being in the United States. Survival of adult patients with sickle cell disease (SCD) has increased progressively since the 1970's. Newborn screening, prophylactic antibiotics, newer vaccines, newer analgesics, safer blood transfusion, chelation therapy and hydroxyurea are some of the reasons for this change in longevity ${ }^{1-4}$. Patients with SCD in their sixth, seventh or eighth decade have been described previously ${ }^{5,6}$. Platt et al. reported that the median age of survival for males with sickle cell anemia was 42 years and for females 48 years.

Aging patients with SCD are at risk to develop comorbiditi ${ }^{1-4}$ es that are not due to SCD itself, but they also become more at risk for developing comorbid conditions that were not previously seen or were rare in this patient population. These include, among other things, diabetes mellitus, rheumatoid arthritis, osteoarthritis, systemic lupus erythematosus, obesity, AIDS, inflammatory bowel disease, hypertension, malignant disorders, etc. The objective of this paper is to review the prevalence of malignancy in aging patients with SCD in our institution in the presence or absence of Hydroxyurea. 
The first case of cancer documented in adult SCD patient was in 1953 By Goldin 7 . In 1986, Stricker $\mathrm{el} \mathrm{al}^{8}$ did a literature review of cancer cases documented so far in adult and pediatric population and added 4 of their own cases. In their report, they suggested that hematologic malignancies were rare events in sickle cell disease population, based on some reports from Africa, Jamaica, Saudi Arabia and United States ${ }^{9-11}$. They attributed this low incidence to be related to short longevity due to complicated disease before getting the chance to develop neoplasia. However, they expected with longer survival, there may be increase in hematologic malignancies due to the hypothesis of increased oncogene expression occurring during erythropoiesis stimulation seen in rats. In 1997, Dawkins et $\mathrm{Al}^{12}$ were the first to attempt to calculate cancer incidence and mortality in SCD patients. The cancer incidence rate was $5 / 2,864$ and mortality rate was $3 / 2,873$. However, there was no control group and they used limited population.

Since then, many case reports and small reviews tried to document cancer cases with no real study assessing the incidence and correlation with sickle cell disease itself. The first study comparing cancer rates in a sickle cell disease cohort and a control cohort was done in 2016 in England by Seminog et al ${ }^{13}$.Using English national dataset of hospital admissions and deaths from 1999 to 2011, 7512 SCD patient were identified. Comparing the sickle cell disease cohort with the cohort without sickle cell disease, the rate ratio for all cancers combined was 2.1, with significantly higher rate of hematological malignancies, including Hodgkin's lymphoma, nonHodgkin's lymphoma, multiple myeloma, lymphoid leukemia and myeloid leukemia among SCD patients. Four solid tumors showed elevated rate ratios in SCD population as well: colon cancer, non-melanoma skin cancer, kidney cancer and thyroid cancer. Again, listing of possible underlying mechanism of cancer in this specific population included: endothelial damage, systemic inflammation, hypoxia, acidosis and compromised apoptosis; exposure to bone marrow transplantation, transfusion-related immunomodulation, and transmission of infections such as viral hepatitis and HIV. Hydrea was mentioned as one possibility, however, no clinical trials had proven it by that time.

A more recent analysis released in 2017 by Brunson et $\mathrm{Al}^{14}$ compared cancer incidence in SCD patient to the general population. 6,423 SCD patients were identified using California database from the Office of Statewide Health Planning and Development. Compared to the California population, SCD patients had a $72 \%$ increased risk of hematologic malignancies and $38 \%$ 
reduced risk of solid tumors. There was two-fold increased risk of leukemia specifically acute myeloid leukemia and chronic lymphocytic leukemia. This risk was increased by four-fold in more severe SCD. There was $38 \%$ reduced risk of solid tumors, specifically, there was lower risk of breast cancer and male genital cancers. Cancer incidence was different than England study, most likely due to different recruitment using highly validated registry data in California study and not hospital coding like in England study. This study also commented on effect of Hydroxyurea on cancer incidence and they mentioned no difference in cancer incidence before and after Hu era use in 1998.

The reduced risk of solid tumors was suggested to be secondary to the ability of sickled erythrocytes to selectively target hypoxic tumor vascular microenvironment and lead to tumor micro vessels occlusion. As for the increased risk of hematologic malignancies, there has been multiple theories behind these findings including Transfusion Related Immune Modulation, iron overload associated with transfusion, and transfusion related infection, chronic inflammation due to sickle cell disease itself, increased RBC proliferation and turn over in the marrow, and possibly hydroxyurea use.

To the best of our knowledge, no studies has been done to evaluate cancer incidence in aging sickle cell patients, especially in hydroxyurea era.

\section{Case series:}

In our study, we are trying to identify malignancies in aging patients with SCD. Looking back in our records, we identified patients who carry the diagnosis of sickle cell disease and malignancy before 2020. We used ICD-10 codes. 483 patients with sickle cell disease were seen in our inpatient and outpatient offices. Among these, 70 were identified with malignancy based on the ICD-10. Further chart reviews confirmed that only 12 SCD patients had confirmed diagnosis of a malignancy. Demographic and clinical data of these patients are presented in table 1.

The mean age of the 12 patients studied was $52.2 \pm 13.4$ years, of the 5 females was $57.8 \pm 10.1$ and of the 7 males was $48.1 \pm 14.0$. The mean age of the 7 living patients was $49.3 \pm 14.0$ years, of the 6 males was $48.7 \pm 15.0$ and of the one female was 53 years. The mean age of the 5 deceased patients was $56.2 \pm 11.3$ years, of these one was male age 45 years and 4 were females aged 59.0 
\pm 111 .0. Although there was no significant difference between females and males in any of these categories of patients, there is a tendency for females to live longer than males and die older than males.

In order to clarify the interrelationships among age, malignancy and $\mathrm{HU}$, we divided the patients into 3 categories as shown in Table 2.

The first group included 2 patients with age ranging from 20-40. Both had hematologic malignancies (Acute Myelogenous Leukemia (AML) and Multiple myeloma) and both were on HU in adulthood (Blue column Table 1).

The second group included 6 patients with age ranging from 40-60 years. One of these (patient $\mathrm{C}$ in Table1) had CML(Chronic Myeloid Leukemia), and the 5 other patients were all diagnosed with solid tumors (oral cavity carcinoma, tongue carcinoma, Renal Cell Carcinoma, pancreatic and gastro intestinal cancer), 2 of these were on $\mathrm{HU}$ in adulthood, and 4 out of the 5 had iron overload (orange column Table 1)

The third group included 4 patients who were older than 60 years, 2 females and 2 males. Only 1 of these patients was exposed to HU in adulthood. They all had multiple myeloma (yellow columns, Table 1).

Patients were considered on Hydroxyurea therapy if they have been taking the drug for more than 6 months. Among the 12 patients, 7 were still alive when we collected data. 6 out of 7 alive patients were on Hydroxyurea. 5 patients were deceased at the time of data collection, and none of them was on hydroxyurea therapy. Prior data have shown decrease mortality rate among this population with hydroxyurea use. Most of our patients who were alive during data collection were treated with hydroxyurea.

\section{Discussion:}

To the best of our knowledge this is the first report about risk of malignancies in aging sickle cell population with or without HU. Patients 60 years and older were all affected by Multiple Myeloma. Most of these patients were not on HU. The combination of SCD and multiple 
myeloma can have a bad outcome. Both are characterized by hyperviscosity, renal failure, bone involvement, and sepsis. The diagnosis of multiple myeloma may be missed initially since the presenting signs and symptom of multiple myeloma may be attributed to VOC or other complications of SCD. Solid tumors were the majority in patients with age ranging from 40-60 and the majority had SS genotype and had signs of iron overload. The number of patients on Hydroxyurea was too small so we cannot make any comment on relationship to malignancy or mortality. It must be emphasized that this study is only one institution experience and the sample size is too small to make definite conclusions. Most of the studies so far have used data base analysis to assess incidence of cancer in sickle cell population. Our experience with this method showed a big mismatch in numbers compared to chart review method. Future studies must be careful how to interpret results coming from data base analysis. Should we be developing newer guidelines for cancer screening in this specific population? And now with the approval of new therapies for SCD, would cancer incidence be changed with time?

1. Le $P Q$, Gulbis $B$, Dedeken $L$, et al. Survival among children and adults with sickle cell disease in Belgium: Benefit from hydroxyurea treatment. Pediatr Blood Cancer. 2015;62(11):1956-1961.

2. Platt OS, Brambilla DJ, Rosse WF, et al. Mortality in sickle cell disease. Life expectancy and risk factors for early death. N Engl J Med. 1994;330(23):1639-1644.

3. Steinberg $\mathrm{MH}, \mathrm{McC}$ arthy WF, Castro $\mathrm{O}$, et al. The risks and benefits of long-term use of hydroxyurea in sickle cell anemia: A 17.5 year follow-up. Am J Hematol. 2010;85(6):403-408.

4. Wierenga KJ, Hambleton IR, Lewis NA. Survival estimates for patients with homozygous sicklecell disease in Jamaica: a clinic-based population study. Lancet. 2001;357(9257):680-683.

5. Ballas SK, Pulte ED, Lobo C, Riddick-Burden G. Case series of octogenarians with sickle cell disease. Blood. 2016;128(19):2367-2369.

6. Steinberg $\mathrm{MH}$, Ballas SK, Brunson $\mathrm{CY}$, Bookchin R. Sickle cell anemia in septuagenarians. Blood. 1995;86(10):3997-3998.

7. Goldin AG, Kelty KC, Beard MF. Sickle cell anemia terminating in acute myeloblastic leukemia. Ann Intern Med. 1953;39(4):920-928.

8. Stricker RB, Linker CA, Crowley TJ, Embury SH. Hematologic malignancy in sickle cell disease: report of four cases and review of the literature. Am J Hematol. 1986;21(2):223-230.

9. Thomas AN, Pattison C, Serjeant GR. Causes of death in sickle-cell disease in Jamaica. Br Med J (Clin Res Ed). 1982;285(6342):633-635.

10. Powars DR. Natural history of sickle cell disease--the first ten years. Semin Hematol. 1975;12(3):267-285.

11. Perrine RP, Pembrey ME, John P, Perrine S, Shoup F. Natural history of sickle cell anemia in Saudi Arabs. A study of 270 subjects. Ann Intern Med. 1978;88(1):1-6.

12. Dawkins FW, Kim KS, Squires RS, et al. Cancer incidence rate and mortality rate in sickle cell disease patients at Howard University Hospital: 1986-1995. Am J Hematol. 1997;55(4):188-192. 
13. Seminog OO, Ogunlaja OI, Yeates D, Goldacre MJ. Risk of individual malignant neoplasms in patients with sickle cell disease: English national record linkage study. J $R$ Soc Med. 2016;109(8):303-309.

14. Brunson A, Keegan THM, Bang H, Mahajan A, Paulukonis S, Wun T. Increased risk of leukemia among sickle cell disease patients in California. Blood. 2017;130(13):1597-1599. 